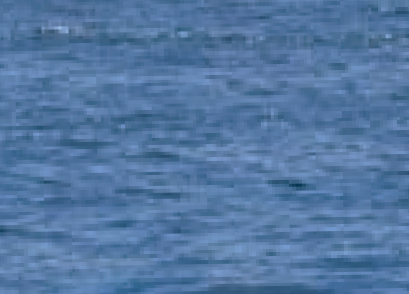

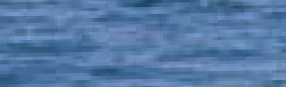

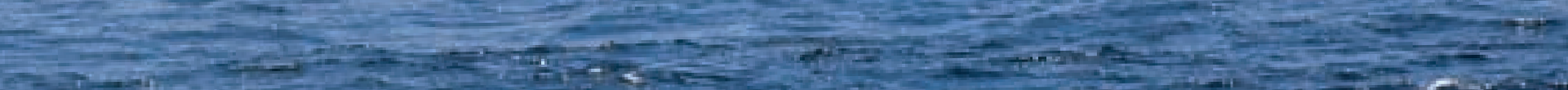

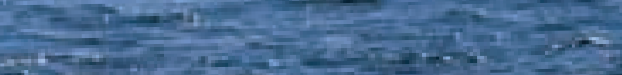

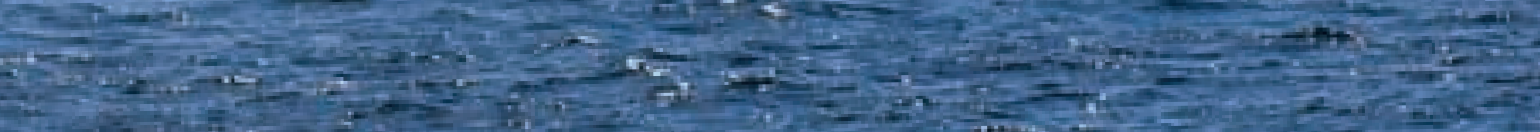

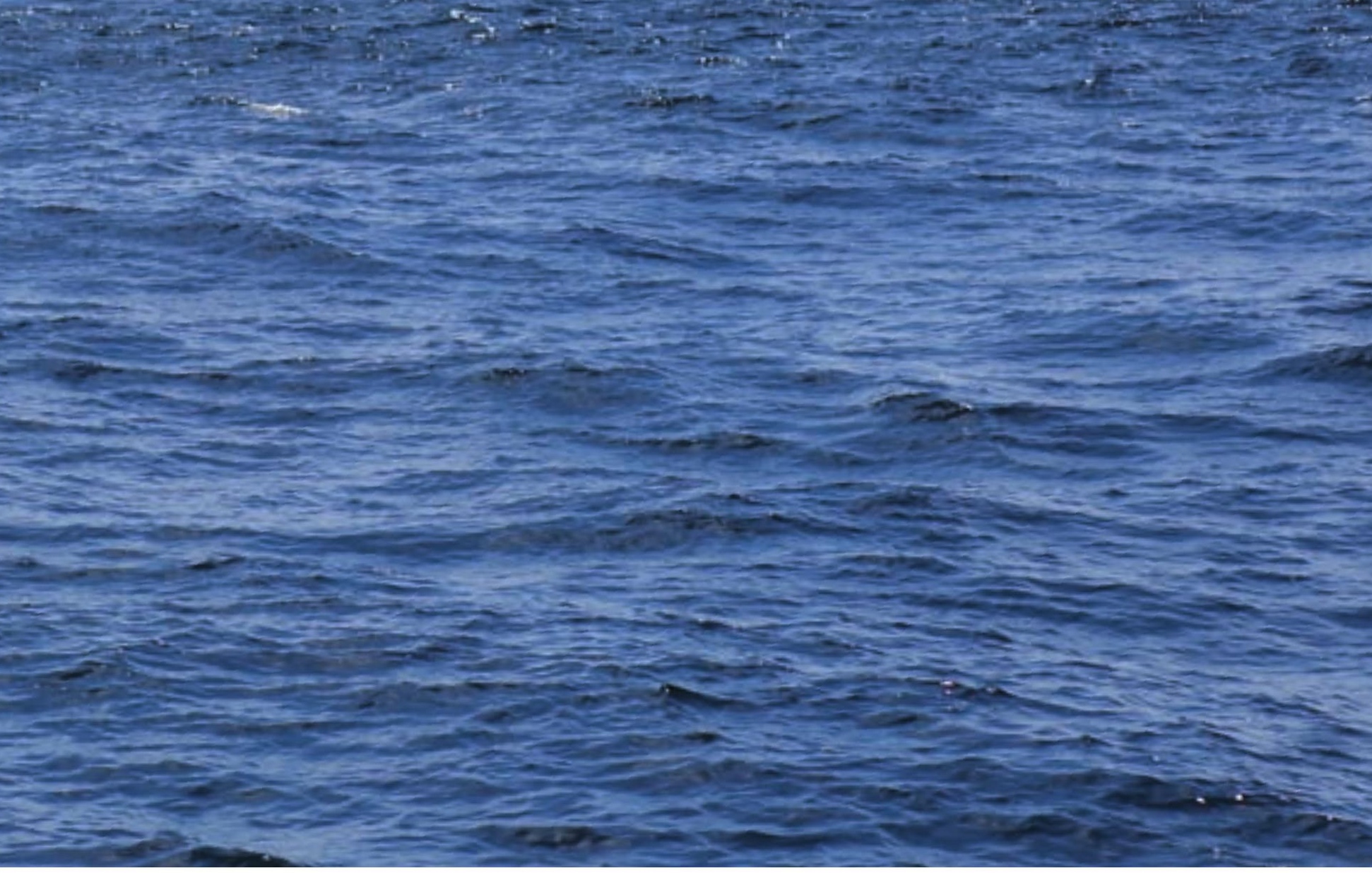




\title{
LA MEMÒRIA OCEÀNICA DEL CLIMA EL SISTEMA CIRCULATORI D'UN PLANETA VIU
}

\author{
Josep L. Pelegrí i Alícia Duró
}

A principis del segle xvı Leonardo da Vinci comparava els corrents oceànics amb el flux de sang d'un cos humà. Actualment disposem d'informació suficient per a explorar la idea que la Terra té un sistema circulatori responsable de capturar, transformar i distribuir l'energia solar. El paper dels oceans com a reguladors del clima és extraordinari, realment condicionen el present i el futur del planeta.

Paraules clau: circulació oceànica, canvi climàtic, oceanografia.

Fa uns cinc-cents anys, a principis del segle xvi, Leonardo da Vinci va tenir la intuïció suficient, i potser fins i tot la imaginació, per a fer una comparació entre els corrents oceànics i el flux de la sang. Ell havia estudiat l'anatomia del cos humà i sabia que el paper de les artèries i les venes és transportar sang oxigenada i amb nutrients cap a totes les parts del cos i convertir-se en la font d'energia per a la vida. Però Leonardo no tenia manera de saber que als oceans hi ha corrents capaços de fer aquest paper global de transferència d'energia al nostre planeta. És aquí on trobem la seva intuïció de geni!

El cos humà incorpora nutrients i oxigen del medi ambient $\mathrm{i}$ els distribueix a totes les cèllules del cos mitjançant el sistema circulatori. El disseny del cos s'ha optimitzat, com a fruit de l'evolució de l'espècie, per aprofitar aquests recursos externs de la millor manera possible. A la Terra també li arriba energia, una font pràcticament inexhaurible de radiació solar, i la Terra, com a sistema viu, també ha evolucionat per tal d'aprofitar-la de la millor manera possible. Ens podem preguntar: on és la vida a la Terra? La resposta és clara: la major massa terrestre on hi ha vida metabòlicament activa són els oceans, molt per sobre de la litosfera, l'atmosfera o la biosfera terrestre. Cal, per tant, que l'energia solar, bé en forma de calor o bé transformada de diverses maneres (com ara en matèria orgànica, producte de la fotosíntesi) pugui arribar a totes les parts del sistema marí. De la mateixa manera cal que els nutrients arribin als llocs on hi ha la transformació fotosintètica. De tot això se n'encarreguen els corrents oceànics que es constitueixen com la baula fonamental per mantenir el flux d'energia i de vida al nostre planeta (Pelegrí, 2008).

Avui dia, a diferència del moment en què vivia Leonardo, ja tenim prou dades per a explorar més quantitativament si veritablement hi ha una analogia entre el flux de les aigües als oceans, com a sistema circulatori del sistema terrestre, i la sang de les artèries i les venes d'un ésser viu superior. I el resultat és que hi ha similituds molt sorprenents. De la mateixa manera que el flux sanguini en els mamífers comença al cor, durant la seva fase de contracció (sístole), també tots els grans corrents oceànics, fora dels més superficials, tenen origen durant l'hivern a les regions més fredes del planeta. La periodicitat bàsica d'aquest sistema circulatori terrestre, o sigui, el temps que triga a bategar, és d'un any. Bé pel refredament de les aigües superficials que es tornen més denses i comencen la seva ruta pels fons marins o bé per l'acció combinada d'aquest refredament i l'acció del vent, els grans corrents inicien la ruta oceà endins durant unes poques setmanes de l'hivern.

I, igual com els éssers vius superiors tenen dos circuits ben diferenciats, també a l'oceà hi ha dues rutes ben definides pels grans corrents oceànics. En els mamífers aquests circuits són el pulmonar i el sistèmic, per a l'oceà aquestes grans rutes són la circulació termoclina i la circulació meridional profunda. El circuit pulmonar és relativament ràpid, en un home adult triga poc menys d'un minut, i és el responsable de portar la sang des del ventricle dret fins als pulmons, on allibera carboni i s'oxigena, per acabar a l'aurícula esquerra. Per contra, el circuit sistèmic és molt més lent, en un 


\section{LEONARDO I LA CURIOSITAT PER L'AIGUA}

L eonardo va néixer l'any 1452 a Vinci, un petit poblet de la regió de Montalbano envoltat de vinyes i d'oliveres, a mig camí entre Florència i Pisa. Semblaria un lloc allunyat del món però en realitat descansa en una de les principals vies de comunicació a Itàlia. Des de molt jove va estar molt interessat en la comprensió de la natura, tant estèticament com conceptualment (Pescio, 2001).

Leonardo és el primer a posar en pràctica el mètode científic, cercava lleis generals a partir de l'experimentació (Pigem, 2009). Harald Höffding presenta el seu pensament com una barreja d'empirisme i naturalisme. Per Leonardo «la saviesa és la filla de l'experiència» que és l'única que permet verificar les intuïcions i teories, ja que «'experiència no enganya mai; són els judicis que s'equivoquen prometent efectes que no són causats per les experimentacions». La seva visió de conjunt és una possible font d'inspiració per als nous enfocaments sistèmics i holístics, per altra banda tan actuals. Encara avui en dia meravella la seva definició de la ciència com a l'observació de tot allò que és possible ("notitia delle cose che sono possibiliv). Es dedica tant a l'observació rigorosa com a
«TALMENT COM LEONARDO, NOMÉS OBRINT ELS ULLS AL PLANETA TERRA COM A CONJUNT PODREM CONĖIXER-LO I CONVIURE-HI MILLOR» fenòmens. Els diferents moviments de l'aigua, els remolins, les onades, la pluja... tot ho estudia amb una amplitud de visió de conjunt alhora que amb una precisió detallista en l'observació. I com a bon científic quan ja havia copsat tot el què volia amb la seva observació, ho havia de contrastar amb altres persones. Així doncs, li agradava conversar sobre el seu element favorit, l'aigua, per tal d'aprendre'n alguna cosa més. I com es pot contemplar en moltes de les seves il.lustracions, tot allò que observa i estudia Leonardo pren forma d'imatge. Les seves observacions sobre els fluxos de l'aigua o les turbulències són reflectides en molts dels seus dibuixos.

Leonardo respecta l'aigua perquè la considera «la sang de la terra». La seva intuïció d'una unitat còsmica, conjuntament amb una predilecció per les analogies, el duu a aquesta semblança entre el cos humà i la Terra: l'un és recorregut pel sistema sanguini, mentre que l'altra ho és per la xarxa de circulació de l'aigua. En trobem un exemple en alguns dels seus quaderns i fragments del Tractat de l'aigua, on s'expressa aquesta idea: "Així com de l'estany de sang provenen les venes, les branques de les quals s'estenen l'experiment i a la formulació exacta de principis generals a partir de l'experiència.

Cap a l'any 1515 va crear les sèries de dibuixos de Deluge dins la collecció de Windsor i del Codex Atlanticus, on representava fenòmens atmosfèrics com ara les tempestes amb llamps i trons i els remolins i diversos fluxos d'aigües. En el seu Tractat de l'aigua fa consideracions sobre la constitució de l'univers i una demostració sobre l'analogia general dels humans i del món. Leonardo vol copsar l'essència dels elements bàsics de la natura (terra, aigua, aire, foc) i comprendre la seva funció (Brion, 1998). Es pregunta de què són fets aquests elements, de quina manera la seva estructura determina el seu funcionament. En aquest cas el Leonardo científic examina les relacions causa i efecte i pensa en lleis. Com s'organitza la natura? Quines relacions existeixen? Quines relacions hi ha entre els éssers vius que participen en la vida d'aquests elements?

Leonardo no és sols un gran pensador sinó també un extraordinari inventor. Sembla que li sigui fàcil concebre el món elemental des de l'observació dels a través del cos humà, així l'oceà omple el cos de la terra amb un nombre infinit de venes aquoses..."

En l'actualitat, mercès a l'oceanografia física s'estudien els moviments de les aigües oceàniques i les seves propietats alhora que es realitzen models que preveuen la possible evolució oceànica i els seus efectes sobre el clima terrestre. És així com la tecnologia i la instrumentació oceanogràfica són els nostres pinzells per dibuixar els paisatges oceànics i estudiar-ne el comportament. Talment com Leonardo, només obrint els ulls al planeta Terra com a conjunt podrem conèixer-lo i conviure-hi millor.

\section{BIBLIOGRAFIA}

BRIon, M.,1998. «Leonardo da Vinci: Alabanza del agua». Elementos, 32: 7. Pescio, Cl., 2001. Leonardo. Art and Science. Giunti Editore S.P.A. Florència-Milà.

PIGem, J., 2009. «La ciència de Leonardo da Vinci». Mètode, 61: 16-19.

Alícia Duró i Josep L. Pelegrí 


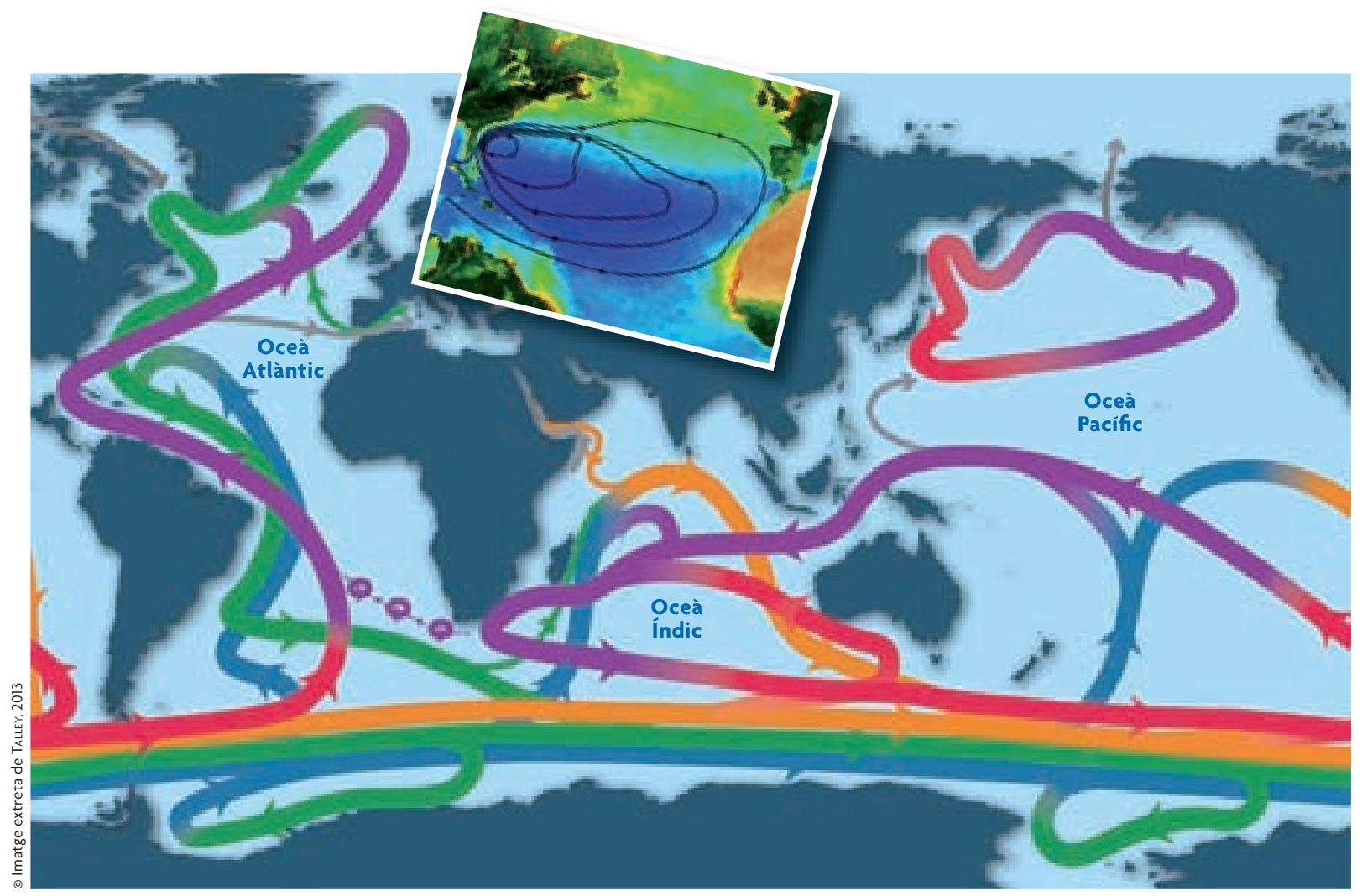

Igual com els éssers vius, que tenen dos circuits sanguinis ben diferenciats, també a l'oceà els grans corrents tenen dues rutes ben definides: la circulació meridional profunda i la circulació termoclina. El dibuix principal ens mostra un esquema de la circulació meridional profunda, que s'inicia als extrems nord i sud de l'Oceà Atlàntic i connecta les aigües fondes (línies blaves i verdes), intermèdies (línies taronges i vermelles) i superficials (línies púrpura) de tots els oceans.

La imatge inserida mostra el color superficial de l'Oceà Atlàntic Nord durant la primavera de 2003, tal com el va veure el sensor de satèl.lit SeaWIFS, amb un esquema de la circulació termoclina que arrenca des de la superfície a altes latituds, revolta la conca oceànica en fondària, i acaba retornant al seu lloc d'origen; circuits semblants tenen lloc a tots els grans oceans de la Terra.

home adult sol trigar de mitjana uns cinc minuts; s'inicia al ventricle esquerre i llavors viatja per tot el cos humà, omplint-se de nutrients als intestins i a l'estómac i portant a tots els músculs del cos aquests nutrients juntament amb l'oxigen, per acabar a l'aurícula dreta.

A l'oceà, l'equivalent del circuit sistèmic és la circulació meridional profunda, popularitzada (Broecker, 1991) amb el nom de «cinta transportadora global» (de l'anglès global conveyor belt) per donar a entendre que es tracta d'una cinta amb dues corrioles, però on sols una és activa, que transporta matèria contínuament per tornar sempre al mateix punt de partida. Es tracta d'un circuit relativament llarg i lent, que trigarà prop de 1.000 anys a tancar-se, quan les aigües retornin a les capes superficials a través de l'oceà Atlàntic equatorial. Aquest circuit, allunyat de l'atmosfera, acaba retornant aigües del fons oceànic, molt riques en nutrients inorgànics, fins a les regions su- perficials. Per altra banda, l'equivalent del circuit pulmonar és la circulació termoclina, on les aigües recorren els mil metres més superficials de les regions subtropicals en un temps relativament curt, de «tan sols» uns deu anys. En començar aquest circuit les aigües són prop de la superfície, en contacte amb l'atmosfera, on es carreguen de matèria orgànica i oxigen, i és quan s'enfonsen que comencen a fer servir aquest oxigen per respirar la matèria orgànica i transformar-la en matèria inorgànica. Així doncs, quan les aigües retornin a la superfície estaran carregades de nutrients, necessaris per a la transformació de l'energia solar en matèria orgànica mitjançant la fotosíntesi (Pelegrí et al., 2006).

El ventricle esquerre del cor terrestre es localitza a les regions subpolars del planeta, tant a l'hemisferi nord (mar del Labrador i mar de Grenlàndia) com al voltant del continent antàrtic. És aquí on cada hivern es formen les aigües 


\section{DETALLS DE LA CAMPANYA OCEANOGRÀFICA}

a campanya MOC2-Equatorial es va dur a terme a bord del vaixell oceanogràfic Hespérides entre el 5 d'abril i el 17 de maig de lany 2010, amb 55 persones tripulants i 34 d'investigadores i tècniques. Aquesta campanya s'emmarcava dins el projecte Memòria oceànica del clima, desenvolupat per personal investigador de l'Institut de Ciències del Mar entre el 2009 i el 2011. La ruta seguida va anar des de la ciutat de Fortaleza (Brasil) fins a Mindelo (Cap Verd). Durant 42 dies es van fer multitud de mesures oceanogràfiques interdisciplinàries a l'Atlàntic Equatorial en dues fases. La primera va cobrir una regió al nord de Brasil fins a $1,5^{\circ} \mathrm{N}$ i $32^{\circ} \mathrm{W}$; la segona va constituir una secció transatlàntica al llarg de $7,5^{\circ} \mathrm{N}$, sortint de Brasil i arribant a Sierra Leone. En total es van fer 110 estacions hidrogràfiques, on, a més d'estudis físics, es van prendre mostres d'aigua a 24 fondàries, des de la superfície fins el fons, en alguns casos a més de 4.000 metres, per fer diverses anàlisis biològiques i biogeoquímiques. A més, en algunes estacions es van llençar a la deriva boies instrumentades, fins un total de catorze.

Les variables mesurades van ser de tres tipus: les dades en continu -que són les que es prenen sense que el vaixell s'aturi-, les que s'obtenen amb boies instrumentades lliurades al mar i les mesures que es fan a les estacions hidrogràfiques. Les dades en continu són de temperatura i de salinitat superficial, dades meteorològiques i velocitat dels corrents fins a uns 500 metres de fondària. Les dades de les boies són de posició, i permeten deduir la velocitat dels corrents, i de temperatura i salinitat a la superfície i a uns $60 \mathrm{~m}$ de fondària. Les mesures a les estacions són les més completes i inclouen variables físiques, químiques i biogeoquímiques. Entre d'altres se n'han mesurat les següents: propietats físiques de l'aigua (salinitat, temperatura, velocitat, fluorescència, terbolesa, cisalla vertical a microescala), oxigen dissolt i nutrients inorgànics (nitrits, nitrats, silicats i fosfats), matèria orgànica (carboni i fòsfor particulat, carboni orgànic i fòsfor total, matèria orgànica dissolta colorada i fluorescent), altres propietats químiques $(\mathrm{pH}$, alcalinitat, metà, carbonats, carboni inorgànic dissolt, clorofluorocarboni, heli) i diverses propietats biològiques (respiració, producció primària, clorofil·la $a$, estructura cel-lular, fitoplàncton, bacteris i algues marines diminutes anomenades parmals).

Alícia Duró i Josep L. Pelegrí molt denses que iniciaran la circulació meridional profunda, un clar batec que representa el punt de partida de les grans artèries profundes. Aquestes aigües inicien el seu gran periple d'un mil·lenni de durada allunyades de l'atmosfera, però, com en tota cinta transportadora, han de retornar al punt de partida. Abans d'arribar a les regions polars de l'hemisferi nord aquestes aigües esdevenen superficials altra vegada a l'oceà Atlàntic equatorial, que es converteix, doncs, en l'aurícula cardíaca dreta: aquí arriben les venes oceàniques amb un pols cardíac estacional que ja és pràcticament imperceptible. Després de gairebé un mil·lenni aconsegueixen retornar a les regions oceàniques illuminades, mantenint un cert senyal de les propietats que tenien quan van escapar de la superfície, com si guardessin encara la memòria dels climes passats de la Terra.

A les aigües que van de camí a l'Atlàntic equatorial, per retornar a la superfície oceànica, les anomenem antàrtiques intermèdies. Es tracta d'aigües relativament dolces i molt fredes, perquè provenen del voltant del

\section{«DESPRÉS DE GAIREBÉ UN MIL.LENNI LES AIGÜES ACONSEGUEIXEN RETORNAR A LES REGIONS OCEÀNIQUES \\ IL.LUMINADES, MANTENINT UN CERT SENYAL DE LES PROPIETATS QUE TENIEN QUAN VAN ESCAPAR DE LA SUPERFÍCIE»}

continent antàrtic, que emmagatzema milions de kilòmetres cúbics de gel. En arribar a la superfície aquestes aigües tenen la capacitat d'incorporar grans quantitats de radiació solar, que posteriorment serà distribuïda cap a latituds més altes (Rahmstorf, 2002). A l'oceà equatorial i tropical els corrents viatgen predominantment en direcció zonal, entre els continents americà i africà. Tots aquests corrents, però, estan connectats amb el marge occidental, on hi ha el corrent del Nord de Brasil. Aquest és un intens corrent meridional, al nord del continent sud-americà, que connecta les aigües de tots dos hemisferis.

El corrent del Nord de Brasil representa la primera de les últimes etapes del llarg viatge de la circulació meridional profunda, iniciada durant un hivern llunyà de fa prop de mil anys; aquestes últimes etapes ja es fan amb corrents superficials, ràpids, així en qüestió de sols un any travessaran el Carib (corrents de Guyana i del Carib) i continuaran al llarg de la costa d'Amèrica de l'Est fins a les regions subpolars (corrent del Golf i corrent Nord-atlàntica). Les aigües del corrent 


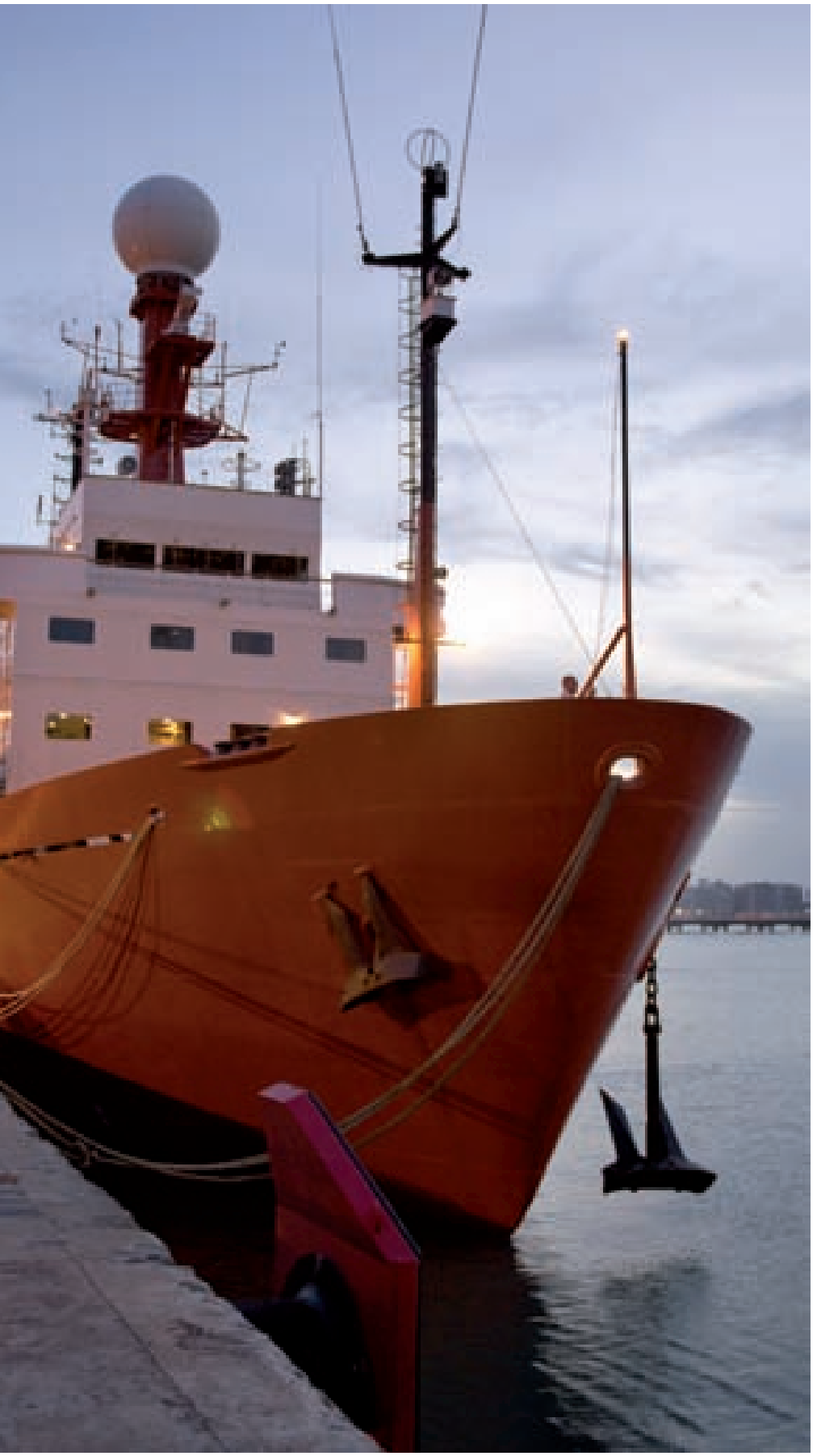

La campanya MOC2-Equatorial es va realitzar a bord del vaixell de recerca oceanogràfica Hespérides des de Fortaleza (Brasil) fins a Mindelo (Cap Verd). En total van ser 42 dies de navegació durant l'abril i el maig del 2010 a l'oceà Atlàntic tropical i equatorial en el qual van participar investigadors de diverses institucions nacionals i internacionals. del Nord de Brasil transporten grans quantitats de calor cap a les regions més septentrionals de l'Atlàntic i permeten, entre altres coses, que l'Europa meridional tingui un clima suau. Part d'aquest flux de calor ve de l'oceà Índic, que és un oceà tancat pel nord, per la qual cosa tota la calor radiativa emmagatzemada a la regió tropical ha d'anar cap al sud i pot parcialment escapar vers l'Atlàntic mitjançant el corrent d'Agulles, però una gran part ve precisament de l'escalfament de les aigües antàrtiques durant el seu trànsit per l'Atlàntic sud i equatorial.

Els investigadors de l'Institut de Ciències del Mar del Consell Superior d'Investigacions Científiques han estudiat aquests processos mitjançant el projecte «Memòria oceànica del clima». Es tractava d'estudiar la fase final del circuit sistèmic terrestre: les regions equatorials on s'ubica el final de la circulació meridional profunda. Aquest projecte ha permès millorar el nostre coneixement sobre el paper dels oceans en el control del clima terrestre, tot estudiant una de les regions de més transcendència sobre el clima de la Terra: l'Atlàntic equatorial.

Una de las activitats principals del projecte ha estat la campanya oceanogràfica MOC2-Equatorial. L'objectiu principal d'aquesta campanya va ser investigar l'abast del transport i les transformacions que han experimentat les aigües intermèdies en el seu viatge des de l'oceà austral fins a l'Atlàntic equatorial. Una pregunta que ens fèiem era: quina és la font d'energia que permet a aquestes aigües fluir cap al nord? Tots els hiverns les aigües profundes es formen a altes latituds de l'Atlàntic nord, però no sabem d'on obtenen l'energia per a retornar a aquestes mateixes regions. L'inici del camí sembla clar: les aigües profundes es formen gràcies al guany en densitat durant el refredament hivernal, això crea un gradient de pressió que les empeny cap al sud. Però és això suficient perquè recorrin milers i milers de quilòmetres al voltant del planeta, a poc a poc pujant per la columna d'aigua, fins que retornin a l'Atlàntic superficial? Els càlculs indiquen que això no és suficient, per tal que l'aigua segueixi aquest llarg periple es requereixen fonts addicionals d'energia. La primera és el fort vent sobre els girs subtropicals, les grans regions centrals oceàniques, i la segona font energètica té lloc a la regió equatorial, mitjançant una meravellosa combinació en la variació estacional de la radiació solar i el sistema de vents tropicals que, com si d'una bomba peristàltica es tractés, porta aquestes aigües vers la superfície i les expulsa cap al nord, fins que són incorporades al sistema zonal de corrents tropicals per arribar al corrent del Nord de Brasil (Castellanos, 2012).

Com a part de la campanya es va realitzar una secció transatlàntica al llarg del paral·lel $7,5^{\circ} \mathrm{N}$. Es trac- 


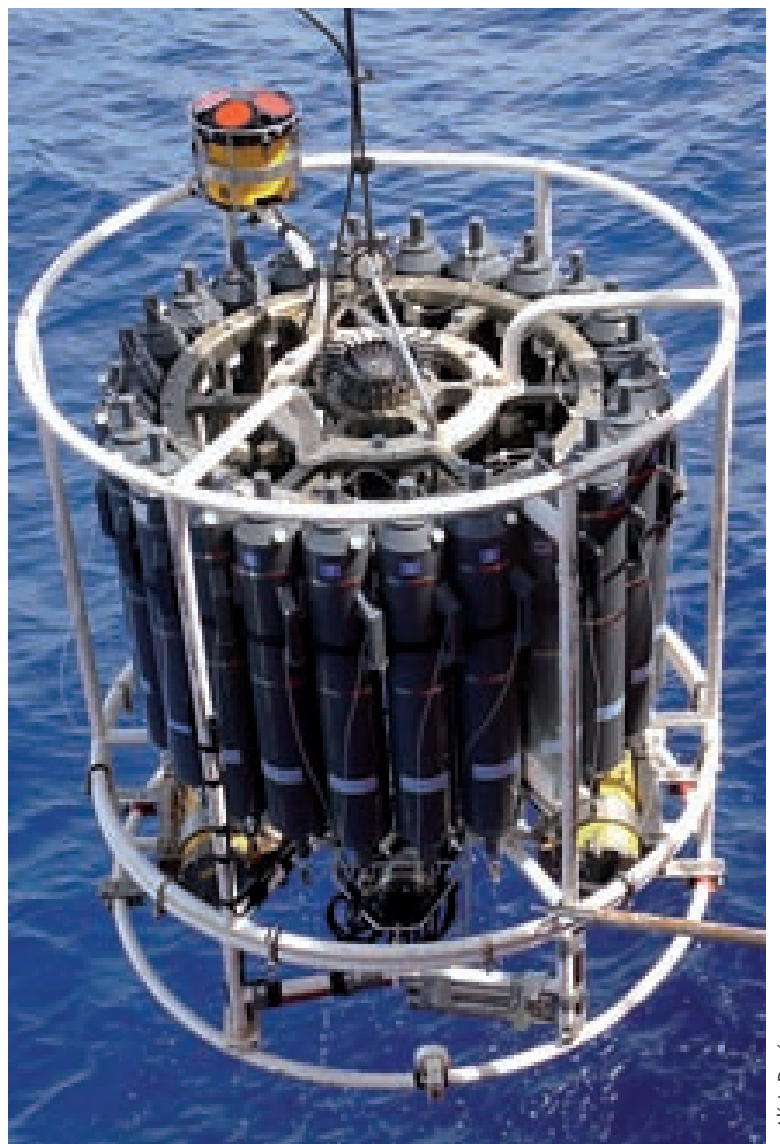

La roseta-CTD-LADCP és una estructura integrada per 24 ampolles de 12 litres cadascuna i nombrosos sensors per a mesurar diverses propietats de la columna d'aigua (salinitat, temperatura, pressió, fluorescència, oxigen dissolt i velocitat del corrent). A més, permet agafar mostres d'aigua a distintes fondàries per a analitzar molts altres paràmetres. Així s'estudia com canvien aquestes propietats amb la fondària i què caracteritza les diferents masses d'aigua.

ta de la quarta vegada a la història de l'oceanografia que s'ha fet aquesta secció. L'oceà absorbeix prop de la meitat del carboni antropogènic, cosa que minva l'efecte hivernacle, però, a més, té la capacitat d'emmagatzemar grans quantitats de calor mitjançant canvis molt petits en la seva temperatura, es tracta del gran regulador de la temperatura del planeta. La importància de la secció al llarg de $7,5^{\circ} \mathrm{N}$ és que ens permet quantificar quanta calor, així com altres propietats com ara el carboni, s'ha incorporat a l'oceà i quin és el flux meridional d'aquestes propietats en les regions equatorials de l'Atlàntic.

Quant als resultats de la campanya, hem pogut determinar l'estructura i les connexions espacials de nombroses propietats en tota aquesta gran regió equatorial. Entre els resultats més específics hem determinat la gran intensitat i profunditat del corrent del Nord de Brasil i hem vist que part d'aquest corrent es desvia

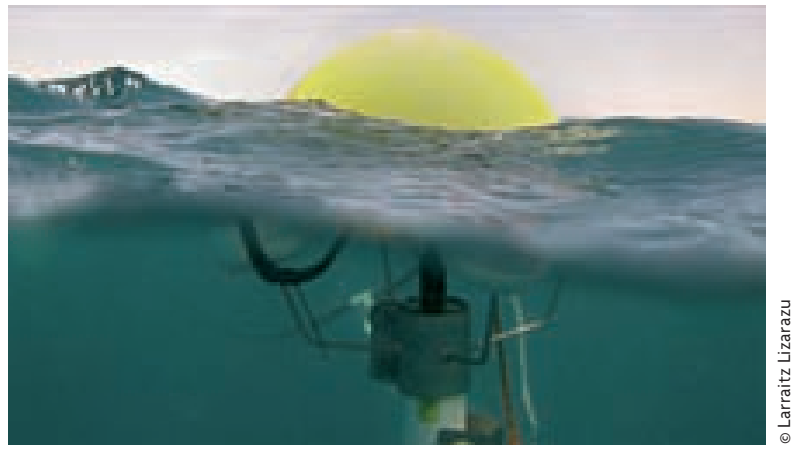

En algunes estacions es van llençar boies instrumentades a la deriva que transmetran informació sobre l'oceà durant els propers anys.

\section{«ELS CANVIS QUE EXPERIMENTA LA TERRA QUAN PASSA D'UN ESTADI GLACIAL A UN ALTRE D'INTERGLACIAL S'ASSEMBLEN ALS QUE EXPERIMENTA EL METABOLISME D'UN ÉSSER VIU QUAN CANVIA D'UN ESTAT DE REPÒS A UN ALTRE DE MAJOR ACTIVITAT»}

cap a l'Est, a l'Equador i vora $7^{\circ} \mathrm{N}$ (però sols d'abril a setembre), i la resta continua Carib endins. Ens ha cridat molt l'atenció veure l'extraordinària complexitat de les distintes masses d'aigua que apareixen en aquesta regió, a molt diferents fondàries, i que la converteixen en un centre neuràlgic on es connecten aigües d'origen austral, subtropical i tropical.

Continuem encara dedicats a estudiar totes les dades obtingudes i a comparar-les amb altres campanyes realitzades el 1957 i el 1993 (Benítez-Barrios, 2011; Claret et al., 2012; San Antolín et al., 2012). Això ens permetrà quantificar la intensitat i la variabilitat temporal de la cinta transportadora en els darrers cinquanta anys i tindrem respostes sobre l'organització espacial i temporal del sistema terrestre. Aquestes dades ens han permès també refermar-nos en la idea d'una fisiologia oceànica, dins la qual hi ha un sistema circulatori responsable de capturar, transformar i distribuir l'energia solar, que guarda moltes semblances amb altres sistemes circulatoris complexos. Aquestes similituds poden ésser en l'estructura espacial, tal com les que hem descrites abans, o també en l'estructura temporal. Així doncs, per exemple, els canvis que experimenta la Terra quan passa d'un estadi glacial a un altre d'interglacial (Paillard, 2001) s'assemblen als que experimenta el metabolisme d'un ésser viu quan canvia d'un estat de repòs a un altre 


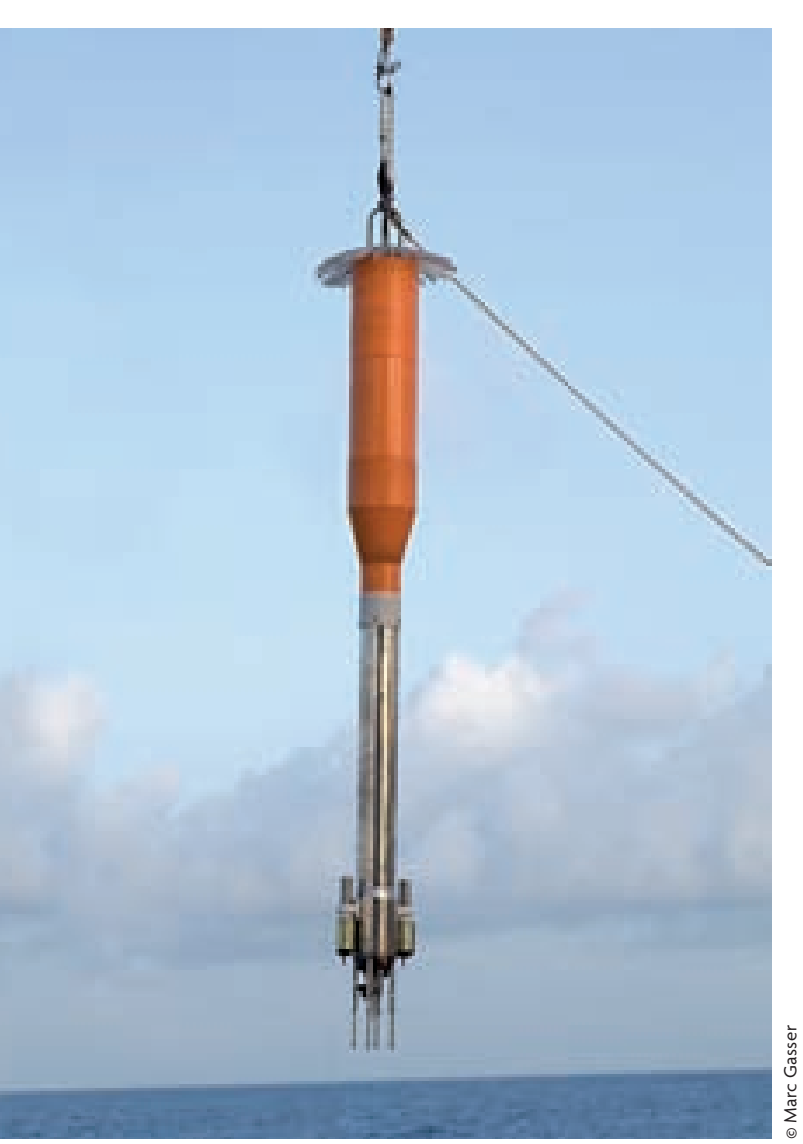

El microperfilador detecta l'estructura a petita escala que hi ha a l'oceà, en petits remolins (de centímetres a metres) on l'energia mecànica es dissipa en forma de calor.

de major activitat (Pelegrí, 2008; Pelegrí et al., en revisió). Per a sostenir aquest increment metabòlic el sistema es mineralitza, és a dir, respira més ràpidament la matèria orgànica i alhora augmenta la taxa de circulació d'aigües profundes, carregades de nutrients, cap a l'oceà superior. El resultat és que a la superfície hi ha més nutrients i per tant augmenta la producció primària, la Terra entra en un estat d'exercici!

Com a conclusió podem dir que els oceans són els responsables del clima present i futur del planeta Terra, són els veritables reguladors del sistema terrestre. No sols la seva massa és molt superior a la massa de l'atmosfera, criosfera, biosfera i pedosfera (la part més exterior, o pell, de la litosfera), sinó que també emmagatzema molta més quantitat d'altres propietats fonamentals per a l'estat de la Terra, tal com són la calor, el carboni i els nutrients inorgànics. Quan contemplem l'oceà en l'horitzó llunyà no ens adonem que sota la seva superfície hi ha un altre paisatge. En canvi, si el mirem cap endins podem veure canvis en les seves propietats que ens parlen de diferents orígens i de molt diverses transformacions tant físiques com biogeoquímiques, que ens expliquen com les diferents aigües es van barrejant al llarg del seu recorregut i com tenen lloc les transformacions entre matèria orgànica i inorgànica.

Estudis com els aquí descrits ens donen eines fonamentals per comprendre quin és el paper dels grans corrents oceànics en la distribució de propietats dins l'oceà, per saber com aquests corrents estan organitzats espacialment i temporalment i per poder anticipar quina pot ser l'evolució futura del clima del nostre planeta.

\section{BIBLIOGRAFIA}

Benítez-Barrios, V. M., 2011. «Multiscale Variability in the North Atlantic Ocean». Tesi doctoral, Universidad de Las Palmas de Gran Canaria.

BroecKer, W. S., 1991. «The Great Ocean Conveyor». Oceanography, 4(2): 18-89. DOI: <10.5670/oceanog.1991.07>

Castellanos, P., 2012. «Wind-driven Currents in the Coastal and Equatorial Upwelling Regions». Tesi Doctoral, Universitat Politècnica de Catalunya.

Claret, M.; Rodríguez, R. i J. L. Pelegrí, 2012. «Salinity Intrusion and Convective Mixing in the Atlantic Equatorial Undercurrent». Scientia Marina, 76(S1): 117-129. DOI: <10.3989/scimar.03611.19B >.

Paillard, D., 2001. «Glacial Cycles: Towards a New Paradigm». Reviews of Geophysics, 39: 325-346. DOI: <10.1029/2000RG000091>.

Pelegrí, J. L., 2008. «A Physiological Approach to Oceanic Processes and Glacial-interglacial Changes in Atmospheric $\mathrm{CO}_{2}$ ». Scientia Marina, 72: 185-202. DOI: $<10.3989 /$ scimar.2008.72n1185>.

Pelegrí, J. L., Marrero-Díaz, A. i A. W. Ratsimandresy, 2006. «Nutrient Irrigation of the North Atlantic». Progress in Oceanography, 70: 366-406. DOI: $<10.1016 /$ i.pocean.2006.03.018>

Pelegrí, J. L.; De la Fuente, P.; Olivella, R. i A. García-Olivares [en premsa]. «Global Constraints on Net Primary Production and Inorganic Carbon Supply During Glacial and Interglacial Cycles». Paleoceanography.

RAHMSTORF, S., 2002. «Ocean Circulation and Climate During the Past 120,000 Years». Nature 419: 207-214. DOI: <10.1038/nature 01090>.

San Antolín Plaza, M. A.; Pelegrí, J. L.; Machín, F. J. i V. M. Benítez, 2012. «Interdecadal Changes in Stratification and Double Diffusion in a Transatlantic Section Along $7.5^{\circ} \mathrm{N} »$. Scientia Marina, 76(S1): $189-$ 207. DOI: $<10.3989 /$ scimar.03616.19G $>$.

TAlLeY, L. D., 2013. «Closure of the Global Overturning Circulation Through the Indian, Pacific, and Southern Oceans: Schematics and Transports.» Oceanography, 26(1): 80-97. DOI: <10.5670/ oceanog.2013.07>

\section{Agraïments:}

La campanya oceanogràtica MOC2-Equatorial es va fer com a part del projecte Memoria Oceánica del Clima: mecanismos y rutas de formación de aguas superficiales en el Atlántico ecuatorial $\left(M O C^{2}\right)$, referència CTM2008-06438-C02-01, finançat pel Ministeri de Ciència i Tecnologia del Govern d'Espanya. Estem molt agraïts al personal tècnic del vaixell, en especial al tècnic en cap José Antonio Pozo, així com a tota la tripulació del Hespérides i al personal científic que va participar en la campanya. Fem també extensiu el nostre agraïment als nostres dos revisors anònims, pels seus comentaris i aportacions a una primera versió d'aquest manuscrit.

Josep L. Pelegrí. Investigador del departament d'Oceanografia Física. Institut de Ciències del Mar, CSIC, Barcelona.

Alícia Duró. Institut de Ciències del Mar, CSIC, Barcelona. 